\title{
THREE NEW SPECIES OF OCOTEA (LAURACEAE) FROM THE BRAZILIAN AtLantic Forest ${ }^{1}$
}

\author{
Leandro C. S. Assis ${ }^{2,4}$ \& Renato de Mello-Silva ${ }^{3,4}$
}

\begin{abstract}
(Three new species of Ocotea (Lauraceae) from Brazilian Atlantic forest) Three new species of Ocotea $-O$. calliscypha L. C. S. Assis \& Mello-Silva, from the state of Minas Gerais, O. ciliata L. C. S. Assis \& MelloSilva, from the state of Espírito Santo, and O. marcescens L. C. S. Assis \& Mello-Silva, from the states of Bahia, Espírito Santo and Rio de Janeiro - are described. The species are illustrated, and comments on their relationships to other species of Ocotea, distribution, habitat, and phenology are provided.
\end{abstract}

Key words: Brazilian Atlantic Forest, Lauraceae, Ocotea, taxonomy.

Resumo

(Três espécies novas de Ocotea (Lauraceae) da floresta atlântica brasileira) Três novas espécies de Ocotea - O. calliscypha L. C. S. Assis \& Mello-Silva, do estado de Minas Gerais, O. ciliata L. C. S. Assis \& MelloSilva, do estado do Espírito Santo e O. marcescens L. C. S. Assis \& Mello-Silva dos estados da Bahia, Espírito Santo e Rio de Janeiro - são descritas. As espécies são ilustradas e comentários, distribuição, habitat, fenologia e relações com outras espécies de Ocotea são fornecidos.

Palavras-chave: floresta atlântica brasileira, Lauraceae, Ocotea, taxonomia.

\section{INTRODUCTION}

Ocotea Aubl. is the largest Neotropical genus of Lauraceae, comprising ca. 300-350 species in the Neotropics plus ca. 50-60 species in Africa and Madagascar (Rohwer 1993, Madriñán 2004). It is not taxonomically well defined, but their species can be distinguished by stamens with four pollen sacs arranged in two pairs above each other, together with additional features such as flowers that generally lack papillae, have free tepals, and either are unisexual or bisexual (van der Werff 1991, 2002). The genus is very diverse in Neotropical rain forests (Rohwer 1986, van der Werff 2002, Madriñán 2004), and it is highly rich in the Atlantic forest of Brazil, where 20$30 \%$ of the species of Ocotea occur (cf. Rohwer 1986, Baitello \& Marcovino 2003, Assis et al. 2005, Quinet 2005). It is a quite threatened biome in need of conservation (Myers et al. 2000), a task that the three new endemic species described here reinforces.

\section{Materials ANd Methods}

This work is based on the analysis of collections housed at B, BHCB, CEPEC, CVRD, K, MO, NY, RB, SPF, SPSF, and UEC herbaria (Thiers, continuously updated). Measures of flowers include the pedicel. The taxonomic species concept is followed, by which a species (as a natural kind; Assis \& Brigandt 2009) is defined by an exclusive feature or a combination of them (Stuessy, 1990). Geographic distribution and habitat complement species circumscription. The classification of vegetation is based on OliveiraFilho \& Fontes (2000).

\section{Results ANd Discussion}

Ocotea calliscypha L. C. S. Assis \& MelloSilva, sp. nov. Type: BRAZIL. MINAS GERAIS: Itambé do Mato Dentro, Distrito de Sant'Ana do Rio Preto, Cabeça de Boi, APA do Parque Nacional da Serra do Cipó, terras de José Agostinho, alto do morro, vegetação

Artigo recebido em 03/2009. Aceito para publicação em 08/2009.

${ }^{1}$ Part of the Ph.D. thesis by the first author at the Universidade de São Paulo, Brazil.

${ }^{2}$ Financial support: FAPESP (03/13176-8; 04/14535-4), IAPT Research Grants in Plant Systematics 2007, and Systematics Association. Current research funding through a PROTAX/CNPq (150929/2009-9) fellowship.

${ }^{3}$ Financial support: CNPq.

${ }^{4}$ Universidade de São Paulo, Depto. Botânica, Lab. Sistemática Vegetal, R. do Matão 277, 05508-090, São Paulo, SP, Brazil.1csassis@ib.usp.br; leandassis@gmail.com 
aberta, perturbada, $19^{\circ} 23^{\prime} 46.9^{\prime \prime} \mathrm{S}, 43^{\circ} 24^{\prime} 07.4^{\prime \prime} \mathrm{W}$, 23.X.2008, fr., M. F. Santos \& J. B. C. Marques 380 (Holotype, SPF; Isotypes, K, MO, RB).

Fig. 1

Species nova O. indecorae accedit sed nervis secundariis plus numerosis, areolis minoribus receptaculo intus glabro, apice antherarum breviore, cupula margine duplicique differt. Proxime est etiam affinis O. odoriferae a qua cataphyllis inferne pubescentibus vel sericeis, receptaculo extus pubescenti apiceque antherarum breviore differt.

Trees 8-12 m tall. Branchlets with rhythmic growth, young branchlets gray to black, glabrous, glabrescent to sparsely pubescent, rhytidome absent, old branchlets gray, glabrous. Leaves generally clustered on the tips of the branchlets; petiole (5-)11-18(-22) $\times 1.5-2.5 \mathrm{~mm}$; lamina (3.1-)10-16.3 X (1.3-) 3-4.3(-5.1) cm, plane, narrowly elliptic to oboval, base acute to obtuse, rarely rounded, apex caudate to slightly caudate, rarely rounded or emarginate, adaxial surface glabrous, venation raised, flat or sunken, abaxial surface glabrous, venation raised, secondary veins $10-16$ pairs, angles with primary vein $35-75^{\circ}$, areoles $0.2-0.5 \mathrm{~mm}$ diam., domatia absent. Cataphylls ca. $5 \times 1.5$ $\mathrm{mm}$, abaxial surface sparse to densely pubescent to sericeous. Inflorescences 2.7$8.5 \mathrm{~cm}$ long, botryoid to thyrsoid, in the axils of cataphylls or the leaves to extra-axillary, axes sparsely pubescent. Flowers $3.8-9 \mathrm{~mm}$ long; pedicel, 1-6 mm long; receptacle 1-2× 1-2.5 $\mathrm{mm}$, outside sparsely pubescent, inside glabrous; tepals $1.5-2 \times 0.5-1.5 \mathrm{~mm}$, elliptic, oval to oblong, adaxial surface sparse to densely papilose, abaxial surface glabrous, glabrescent to sparsely pubescent; stamens 9 , whorls I and II 0.9-1.5 mm long, filaments $0.4-0.6 \mathrm{~mm}$ long, sparse to densely pubescent, anthers $0.5-0.7$ $\times 0.5-0.6 \mathrm{~mm}$, elliptic, oval to oblong, sparsely papilose, apex 0.05-0.1 mm long, rounded, obtuse, acute, emarginate to truncate, upper and lower pollen sacs introrse to latero-introrse, whorl III $1-1.5 \mathrm{~mm}$ long, filaments $0.4-0.7 \mathrm{~mm}$ long, densely pubescent, anthers $0.5-0.7 \times \mathrm{ca}$. $0.5 \mathrm{~mm}$, elliptic, oblong to trapeziform, sparsely pubescent-papilose, apex rounded, truncate to emarginate, upper pollen sacs latrorse, lower pollen sacs latero-extrorse, pair of glands at the base of the whorl III stamens present, staminodia 3 (whorl IV), 0.5-0.7 mm long, clavate to sagittate, sparse to densely pubescent; ovary $1-1.2 \mathrm{~mm}$ long, ellipsoid, style $0.5-0.8 \mathrm{~mm}$ long. Cupules 0.9-1.6 × 1.5-2.1 cm, obconic, margin double and thick, entire to slightly undulate after development of fruits, lenticels densely present, tepals deciduous. Immature fruits $0.8-1 \times 0.8-1 \mathrm{~cm}$, ellipsoid to ovoid.

Ocotea calliscypha are trees endemic to lower montane semi-deciduos forest from Minas Gerais state. It flowers from January to October and fruits from March to October.

Ocotea calliscypha is included in the $O$. indecora group (Rohwer 1986; Assis et al. 2005), which has 20 species and is defined by a unique morphological synapomorphy, the rhythmic growth of the branchlets (Assis 2009). Within the group, the new species can be distinguished by the leaves with $10-16$ pairs of secondary veins and areoles $0.2-0.5 \mathrm{~mm}$ diam., by the cataphylls with pubescent to sericeous abaxial surface, the receptacle pubescent outside and glabrous inside, the apex of the anthers ca. $0.1 \mathrm{~mm}$ long, and cupules with double and thick margin. Ocotea calliscypha is quite similar to O. indecora (Schott) Mez and $O$. odorifera (Vell.) Rohwer, and one of the paratypes has been misidentified as $O$. odorifera (e.g., Chanderbali et al. 2001, p. 110). However, $O$. indecora, a widespread and morphologically variable species, has leaves with 7-12(-14) secondary veins per side and areoles $0.5-1.5 \mathrm{~mm}$ diam., the receptacle inside pubescent and outside glabrous to pubescent, and the apex of the anthers $0.1-0.5 \mathrm{~mm}$ long, and cupules with a single margin. Nevertheless, Ocotea odorifera is widespread and has the abaxial surface of the cataphylls and the outer surface of the receptacle glabrous, the apex of the anthers $0.1-0.4 \mathrm{~mm}$ long, and cupules with inconspicuous double margin.

Paratypes: Belo Horizonte, Parque Ecológico da CEMIG, aprox. $3 \mathrm{~km}$ ao SE de Belo Horizonte, mata, 20.I.1995, fl., F. G. Lorea 5578 (MO not seen, SPSF); 


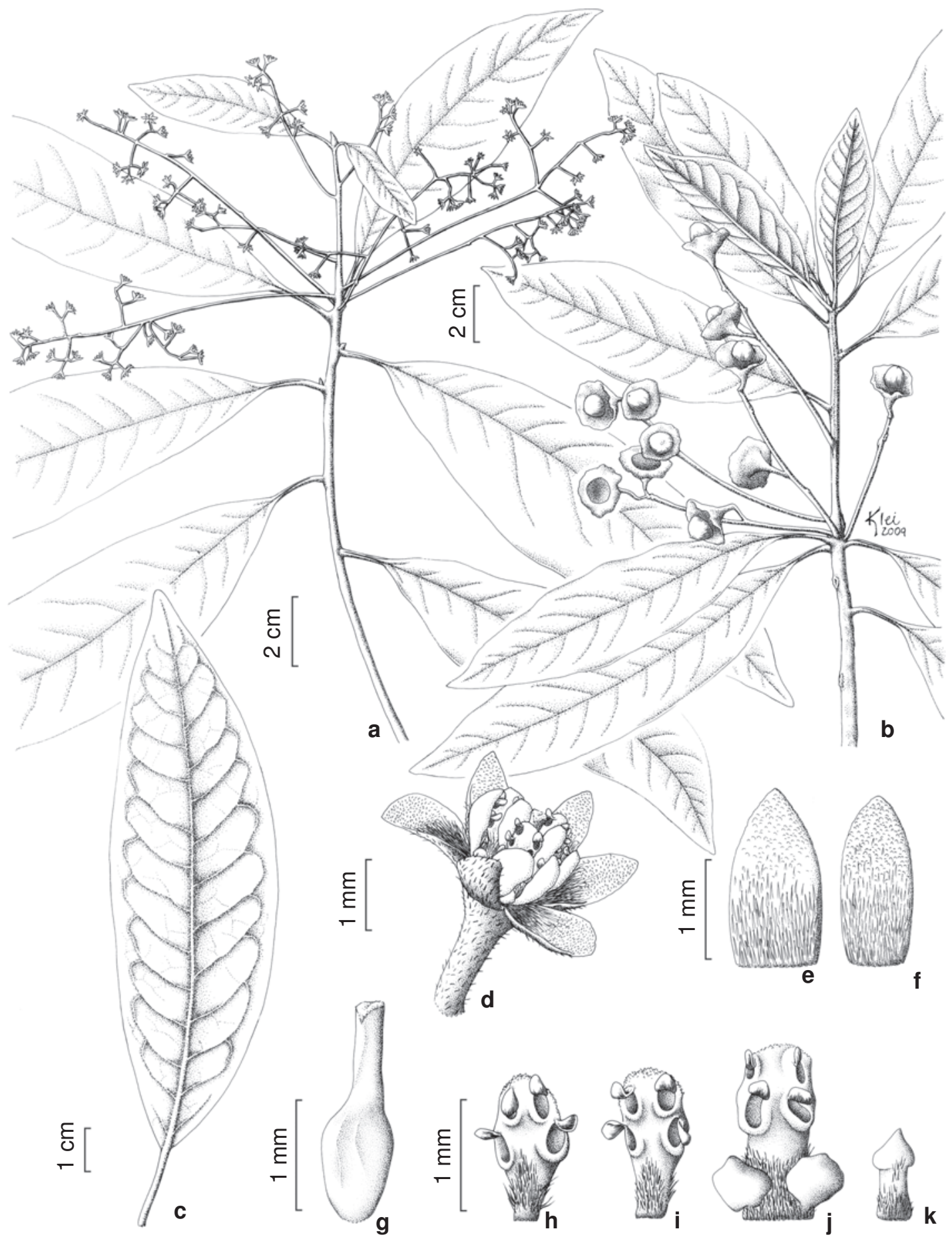

Figure 1 - Ocotea calliscypha L. C. S. Assis \& Mello-Silva - a. flowering branchlet; b. fruiting branchlet; c. detail of abaxial surface of leaf; $d$. detail of flower; e. adaxial side of tepal of the outer whorl; $f$. adaxial side of tepal of the inner whorl; g. gynoecium; h. abaxial side of stamen of the whorl I; i. abaxial side of stamen of the whorl II; j. adaxial side of stamen of the whorl III; k. adaxial side of staminodium of the whorl IV. (a, c-k F. G. Lorea 5578, SPSF; b M. S. Santos \& J. B. C. Marques 380, SPF). 
Itambé do Mato Dentro, Distrito de Sant'Ana do Rio Preto, Cabeça de Boi, APA do Parque Nacional da Serra do Cipó, subida do morro das terras de José Agostinho, pela parte esquerda da mata, 19²3'46.9'’S, 4324'07.4”'W, 16.III.2008, fr., M. F. Santos 322 (BHCB, K, NY); terras de José Agostinho, alto do morro, 23.X.2008, fl., M. F. Santos \& J. B. C. Marques 390 (SPF).

Ocotea ciliata L. C. S. Assis \& Mello-Silva, sp. nov. Type: BRAZIL. ESPÍRITO SANTO: Guarapari, ES-477, estrada que liga a rodovia do Sol (ES-060) à rodovia BR-101, a ca. 3 km rodovia do Sol, fazenda Bonanza, ca. $20^{\circ} 32^{\prime} \mathrm{S}$, $40^{\circ} 25^{\prime}$ W, 18.V.2000, fl. e fr., P. Fiaschi, J. R. Pirani, J. Mafezoli \& F. Petacci 271 (Holotype, SPF; Isotypes, K, MO, NY, RB). $\quad$ Fig. 2

Proxima est affinis $\mathrm{O}$. indecorae sed cataphyllis inferne glabris margine ciliato differt. Proxime affinis etiam est $\mathrm{O}$. odoriferae et $\mathrm{O}$. proliferae, receptaculo intus dense pubescenti, cupulisque margine unico nullo negotio eas discernere.

Treelets 3-7 m tall. Branchlets with rhythmic growth, young branchlets gray to brown, glabrous, sparse to densely pubescent, rhytidome absent, old branchlets gray to brown, glabrous. Leaves clustered on the tips of the branchlets; petiole 4-10(-13) × 0.8-1 mm; lamina (4.5-)7-13.7 $(-16.8) \times(1.2-) 1.8-4.8(-5.5) \mathrm{cm}$, plane, elliptic to narrowly elliptic, base acute to obtuse, apex acute to caudate, adaxial surface glabrous, venation flat to raised, abaxial surface glabrous, secondary veins $10-13$ pairs, angles with primary vein $55-87^{\circ}$, areoles $0.3-1.2 \mathrm{~mm}$ diam., domatia absent. Cataphylls $1-6 \times 0.5-1.2 \mathrm{~mm}$, abaxial surface glabrous, margins ciliate, rarely glabrous. Inflorescences 1.2-2.6(-3.5) cm long, botryoid to thyrsoid, in the axils of the cataphylls or leaves, axes glabrous to sparsely pubescent. Flowers 4-7 mm long; pedicel 0.5-3 mm long; receptacle $1-1.8 \times 2-2.8 \mathrm{~mm}$, inside densely pubescent, outside glabrous; tepals 2.2-2.9($3.3) \times 1.2-1.7 \mathrm{~mm}$, oval, narrowly oval, oblong to oboval, adaxial surface sparse to densely papilose, abaxial surface glabrous; stamens 9, whorls I and II 1.2-1.6 mm long, filaments (0.2-)0.4-0.7 mm long, sparse to densely pubescent, anthers $0.7-1.2 \times(0.4-) 0.7-1.1 \mathrm{~mm}$, elliptic, circular, oval to broadly oval, sparse to densely papilose, apex $0.1-0.3 \mathrm{~mm}$ long, acute, obtuse to rounded, upper pollen sacs introrse, lower pollen sacs latero-introrse, whorl III 1$1.5 \mathrm{~mm}$ long, filaments $0.3-0.6 \mathrm{~mm}$ long, glabrescent to sparsely pubescent, anthers 0.6$0.8 \times 0.3-0.7 \mathrm{~mm}$, elliptic, oblong, oval to obtrapeziform, sparsely papilose, apex truncate to rounded, upper and lower pollen sacs lateroextrorse, pair of glands at the base of the whorl III stamens present, staminodia 3 (whorl IV) or absent, (0.4-)0.6-0.9 mm long, fusiform to clavate, sparse to densely pubescent; ovary 0.9$1.1 \mathrm{~mm}$ long, ellipsoid, ovoid to obovoid, style (0.3-)0.6-0.7 mm long. Cupules (0.8-)1.7-1.9 $\times(1.5-)$ 1.9-2 cm, obconic, margin single, entire after development of fruits, lenticels absent, rarely present, tepals deciduous. Fruits 2-2.1 × 1.2-1.8 cm, ellipsoid.

Ocotea ciliata are treelets endemic to lowland rain forest, including tabuleiro forest, in the state of Espírito Santo. It flowers from May to November and fruits from May to July. Ocotea ciliata can also be included in $O$. indecora group, within which it can be distinguished by leaves with the angles between the secondary and primary veins $55-87^{\circ}$, the cataphylls glabrous at the adaxial surface, with ciliate margins, by the receptacle glabrous outside and densely pubescent inside, and by cupules with one single margin. It resembles O. indecora (Schott) Mez, a widespread species in lowland, submontane, lower montane, and upper montane rain, semi-deciduous and Araucaria mixed forests from southern Bahia to southern Brazil and Paraguay. However, O. indecora has leaves with the angles between the secondary and primary veins $20-72^{\circ}$, domatia absent to present, the cataphylls sparsely to densely pubescent on the adaxial surface, and the receptacle glabrous to pubescent outside. The ciliate margins of the cataphylls, after which the species is named, also occur in other species of $O$. indecora group, namely $O$. fasciculata (Nees) Mez, O. odorifera (Vell.) Rohwer, and $O$. prolifera (Nees \& Mart.) Mez. Nevertheless, O. fasciculata has arcuate leaves and anthers of the whorls I, II, and III 


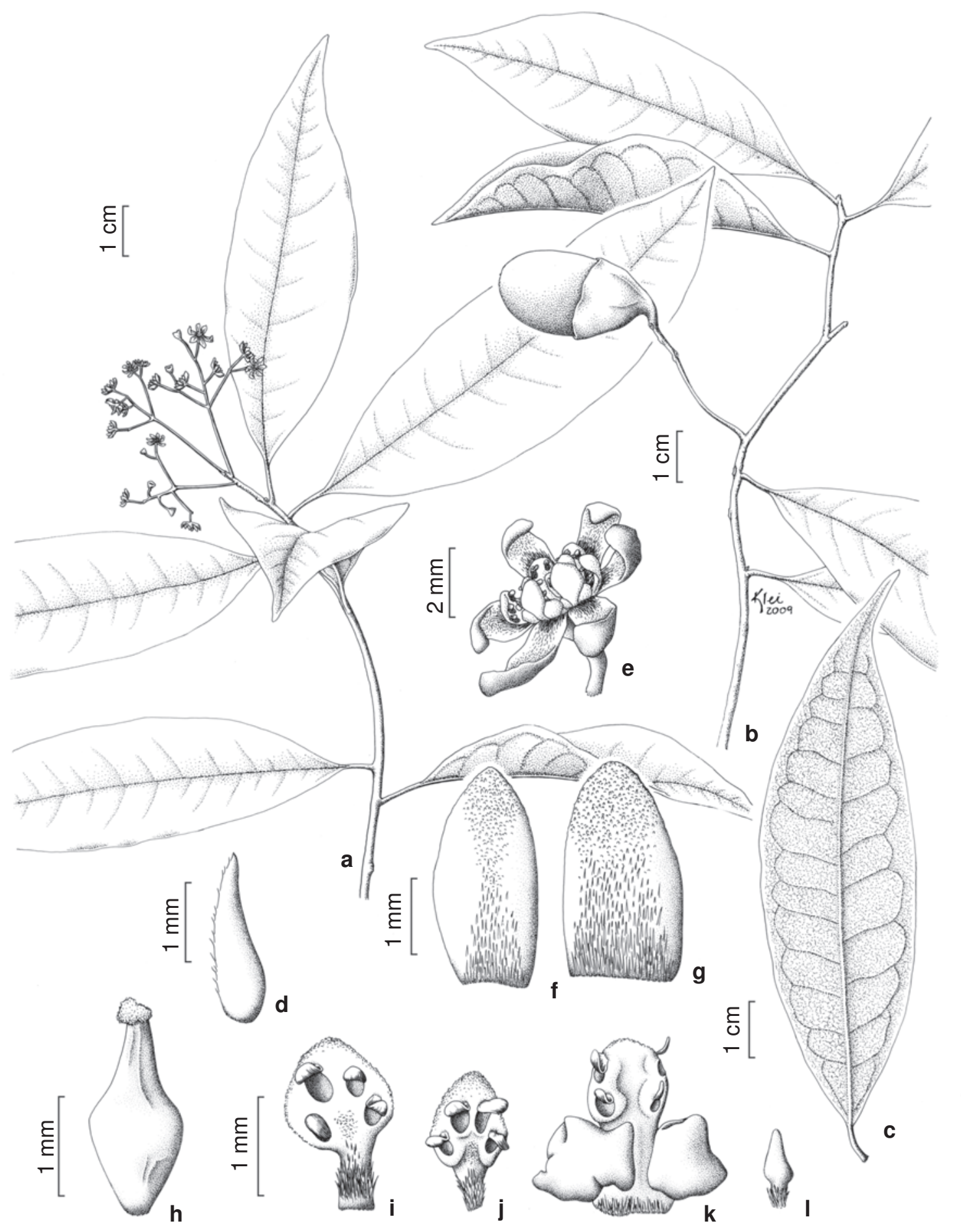

Figure 2 - Ocotea ciliata L. C. S. Assis \& Mello-Silva - a. flowering branchlet; b. fruiting branchlet; c. detail of abaxial surface of leaf; d. detail of abaxial side of cataphyll; e. detail of flower; f. adaxial side of tepal of the outer whorl; g. adaxial side of tepal of the inner whorl; h. gynoecium; i. abaxial side of stamen of the whorl I; j. abaxial side of stamen of the whorl II; k. adaxial side of stamen of the whorl III; 1. adaxial side of staminodium of the whorl IV. (a-1 P. Fiaschi et al. 271, SPF). 
0.3-1 mm long; and $O$. odorifera and $O$. prolifera have the leaves with the angles between the secondary and primary veins 30$75^{\circ}$, the receptacle inside glabrous to glabrescent, and cupules with inconspicuous double margin. In addition, $O$. odorifer and $O$. prolifera have almost the same distribution as $O$. indecora. Paratypes: BRAZIL. ESPÍRITO SANTO: Linhares, Reserva Biológica da Companhia Vale do Rio Doce, rodovia BR-101, km 120, estrada Gávea, km 16.324, centro ou lado esquerdo do bloco 4, ensaio de prod. sustent., mata de tabuleiro, 22.IX.1982, fl., D. A. Folli 399 (CEPEC, CVRD, MO not seen, SPF); Estrada Sapucaia Vermelha, km 1.8, mata de tabuleiro, 17.VII.2002, D. A. Folli 4292 (CVRD, MO not seen, SPF); Estrada Flamengo, próximo ao laboratório de sementes, lado esquerdo da estrada, 1909'02.1'S, 4004'15'W, elev. 70 m, floresta de tabuleiro, 7.VII.2006, fl. e fr., L.C.S. Assis, L.M. Borges, G. Siqueira \& M. Trovo 1163 (B, CVRD, NY, RB, SPF).

Ocotea marcescens L. C. S. Assis \& MelloSilva, sp. nov. Type: BRAZIL: ESPÍRITO SANTO: Linhares, Reserva Biológica da Companhia Vale do Rio Doce, rodovia BR101, km 120, estrada Bicuíba, km 0.91, mata de tabuleiro, 4.VIII.2004, fr., D. A. Folli 5090 (Holotype, SPF; Isotype, CVRD). Fig. 3

Species quam affinis $\mathrm{O}$. mosenii quae facile tamen distinguitur coflorescentiis squamatis vel foliatis, tepalis inferne sparce denseve pubescentibus quoque marcescentibus revolutisque.

Trees 20-30 m tall. Branchlets with rhythmic growth, young branchlets brown, sparse to densely pubescent to tomentose, rhytidome absent, old branchlets gray to brown, glabrous. Leaves generally clustered on the tips of the branchlets; petiole $3-15 \times$ 1.5-2 mm; lamina (2.1-)2.6-7.8(-8.5) × (0.8-) $1.4-4.1 \mathrm{~cm}$, arcuate, rarely plane, elliptic to oval, rarely orbicular or narrowly elliptic, base obtuse to rounded, apex caudate to slightly caudate, rarely rounded or emarginate, adaxial surface glabrous, venation raised, flat or sunken, abaxial surface glabrous to glabrescent, venation raised, secondary veins $7-11$ pairs, angles with primary vein $45-60\left(-80^{\circ}\right)$, areoles 0.5-1.7 mm diam., domatia absent. Cataphylls
1-5×1-2 mm, abaxial surface densely tomentose to sericeous. Inflorescences (1.5-)2.1-9 cm length, botryoid to thyrsoid, in the axils of cataphylls or leaves to extra-axillary, axes sparsely to densely pubescent to tomentose, bracts of the coflorescences foliaceous to scale-like. Flowers (4-)7-13.5(-15) mm long; pedicel (0.5-)1.5-8.5(-10) mm long; receptacle $0.8-2 \times 1.2-2.5 \mathrm{~mm}$, outside densely pubescent, inside sparse to densely pubescent; tepals $2.2-$ $4.2 \times(0.8-) 1.2-2.5 \mathrm{~mm}$, elliptic, oval, oboval to oblong, adaxial surface densely papilose, abaxial surface sparse to densely pubescent; stamens 9, whorls I and II 0.9-1.6 mm length, filaments (0.05-)0.1-0.6 mm long, rarely absent, densely pubescent, anthers $0.6-1.1 \times$ 0.5-1 mm, elliptic, oblong, oval, circular, square to transversely oblong, sparse to densely papilose, apex 0.1-0.3 mm long, rounded, acute, obtuse to truncate, upper pollen sacs introrse, lower pollen sacs introrse to laterointrorse, whorl III 0.8-1.4 mm long, filaments (0.05-)0.3-0.7 mm long, rarely absent, sparse to densely pubescent, anthers $0.4-0.8 \times 0.4$ $0.7 \mathrm{~mm}$, oblong, transversely oblong, oboval, obtrapeziform to square, rarely elliptic or transversely elliptic, sparsely papilose, apex rounded, obtuse, emarginate to truncate, upper pollen sacs latrorse to latero-extrorse, lower pollen sacs latero-extrorse, pair of glands at the base of the whorl III stamens present, staminodia 3 (whorl IV) absent to present, (0.4-)0.6-1 mm long, clavate to fusiform, sparsely to densely pubescent; ovary $0.8-1.4$ mm long, ellipsoid, style $0.4-0.9 \mathrm{~mm}$ long. Cupules $0.7-1.1 \times 0.8-1.3 \mathrm{~cm}$, hemispheric, margin double, entire after development of fruits, lenticels present to absent, tepals persistent and revolute. Fruits $1.5-1.8 \times 0.7-1$ $\mathrm{cm}$, ellipsoid to ovoid.

Ocotea marcescens are large trees that grow on lowland rain forest, including tabuleiro forest, in the states of Bahia and Espírito Santo, and lowland and submontane rain forests in the state of Rio de Janeiro. It flowers from June to September and fruits from May to July.

Ocotea marcescens can also be included in the $O$. indecora group. Within the group, 


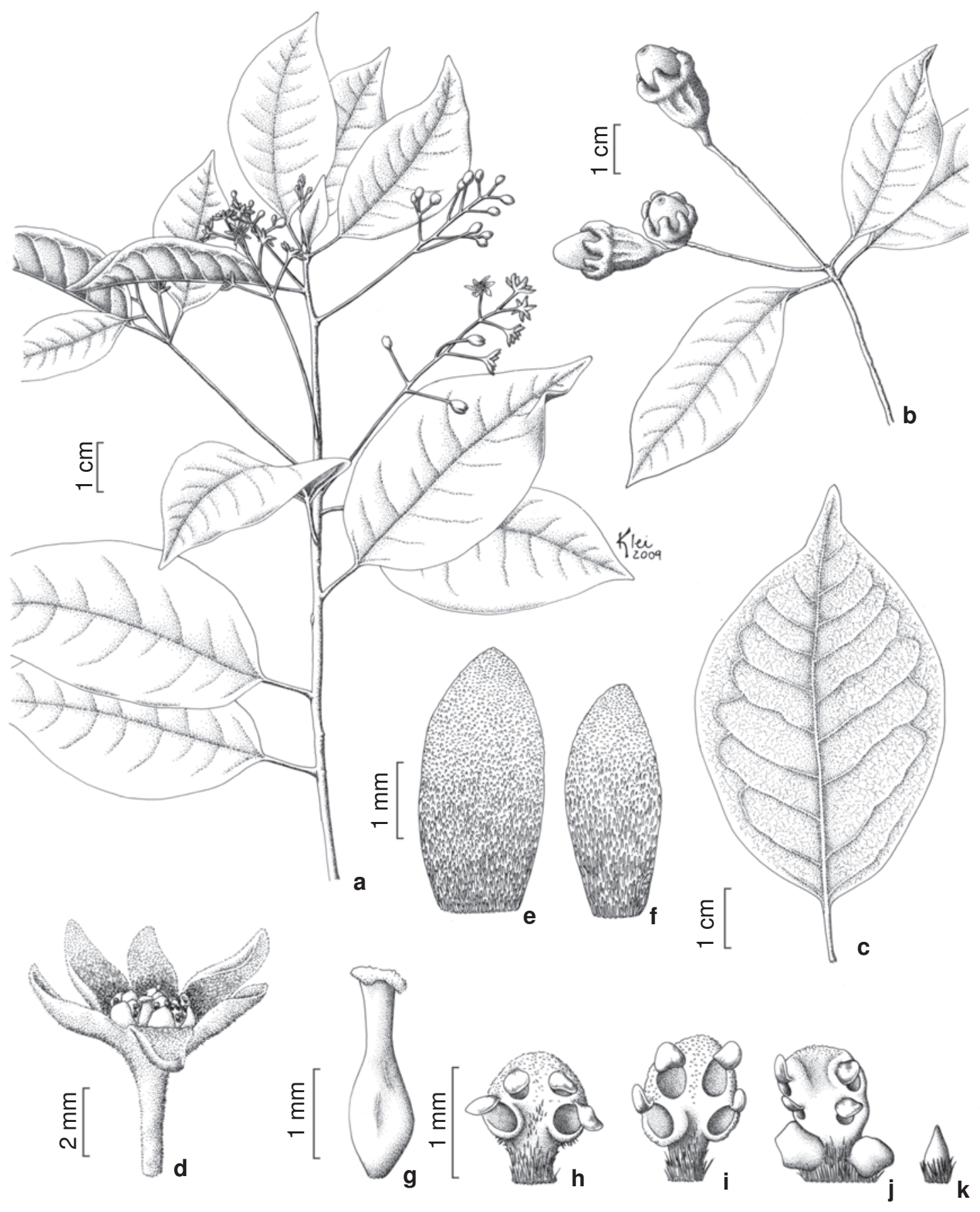

Figure 3 - Ocotea marcescens L. C. S. Assis \& Mello-Silva - a. flowering branchlet; b. fruiting branchlet; c. detail of abaxial surface of leaf; d. detail of flower; e. adaxial side of tepal of the outer whorl; f. adaxial side of tepal of the inner whorl; $g$. gynoecium; h. abaxial side of stamen of the whorl I; i. abaxial side of stamen of the whorl II; j. adaxial side of stamen of the whorl III; k. adaxial side of staminodium of the whorl IV. (a, c-k D. A. Folli 321, SPF; b D. A. Folli 5090, SPF). 
the new species can be distinguished by the tepals sparse to densely pubescent on the abaxial surface, the bracts of the coflorescences foliaceous to scale-like, and cupules with double margin ornated with the persistent and revolute tepals, hence the epithet name. It resembles $O$. mosenii Mez, which is endemic to semi-deciduous and rain submontane forests in the state of São Paulo. However, O. mosenii has tepals sparsely pubescent on the abaxial surface, bracts of coflorescences always scale-like, and the tepals, although also persistent, are involute. Both species have leaves generally arcuate resembling $O$. fasciculata which nevertheless has cupules with a single margin and deciduous tepals. Cupules with double margin are also found in O. calliscypha, and inconspicuously in $O$. odorifera and $O$. prolifera, but in these species the leaves are always plane and the tepals are deciduous at fruiting stage.

Paratypes: BRAZIL. BAHIA: Itabela/Eunápolis, saída de Itabela/Eunápolis, $1 \mathrm{~km}$ da rodovia BR-101, lado leste, 13.IX.1968 (fl.), J. Almeida \& T. S. Santos 29 (CEPEC, RB); Una, $\mathrm{km} 40$ of the rodovia Rio Branco/ Una, fazenda Dendhevea, mata, 11.IX.1974, fl., T. S. Santos 2801 (CEPEC, RB). ESPÍRITO SANTO: Linhares, Reserva Biológica da Companhia Vale do Rio Doce, rodovia BR-101, km 120, estrada Macanaíba-Pelede-Sapo, km 3.45, mata de tabuleiro, 14.IX.1973, fl., J. Spada 307/73 (CVRD, SPF); Estrada Mantegueira, km 0.403, mata de tabuleiro, 25.VIII.1981,fl., D. A. Folli 321 (CVRD, SPF, UEC); Estrada Orelha-de-Macaco, km 0.426, 3.IX.1981, fl., D. A. Folli 323 (CVRD, SPF); 10.VI.1982, fr., D. A. Folli 379 (CVRD, SPF); Estrada Roxinho, km 0.254, 15.V.1982, fr., I. A. Silva 328(CVRD, SPF, UEC); Estrada Bicuíba, km 0.9. mata de tabuleiro, 4.VIII.2005, fr., D. A. Folli 5089 (CVRD, SPF); Estrada Bicuíba, lado esquerdo da estrada, 1909'27.8'S, 4002'20.6'W, elev.74 m, floresta de tabuleiro, 7.VII.2006, fr., L. C. S. Assis, L. M. Borges, G. Siqueira \& M. Trovó 1164 (CVRD, K, SPF). RIODEJANEIRO: Riode Janeiro, Horto Florestal, 27.VI.1927, fl. e fr., Pessoal do Horto Florestal s.n. (K, MBM not seen, MO not seen, NY not seen, RB 139859, SI not seen, SPF).

\section{ACKNOWLEDGEMENTS}

We thank Tiago Barbosa, Leonardo Borges, Matheus Santos, Marcelo Trovó, Marccus Alves, and two anonymous reviewers for helpful discussions and/or comments on an early version of this article; Geovane Siqueira and Domingos Folli for helpful fieldwork support in Reserva Biológica da Companhia Vale do Rio Doce, Linhares; Matheus Santos for collecting specimens of one of the new species; and Rafaela Forzza for introducing and encouraging the first author in Lauraceae systematics. We also thank the curators of the visited herbaria.

\section{Bibliographic ReFERENCES}

Assis, L. C. S. 2009. Sistemática e filosofia: filogenia do complexo Ocotea e revisão do grupo Ocotea indecora (Lauraceae). Ph.D. Thesis. Universidade de São Paulo, São Paulo. 226p.

Assis, L. C. S. \& Brigandt, I. 2009. Homology: homeostatic property cluster kinds in systematics and evolution. Evolutionary Biology: 36(2): 248-255.

Assis, L. C. S.; Forzza, R. C. \& van der Werff, H. 2005. A família Lauraceae na Reserva Biológica da Represa do Grama, Descoberto, Minas Gerais, Brasil. Boletim de Botânica da Universidade de São Paulo 23(1): 113-139.

Baitello, J. B. \& Marcovino, J. R. 2003. Lauraceae: Ocotea Aubl. In: Wanderley, M. G. L.; Shepherd, G. J.; Giulietti, A. M. \& Mehem, T. S. Flora fanerogâmica do Estado de São Paulo. FAPESP, RiMa, São Paulo, 3: 179-208.

Chanderbali, A. S.; van der Werff, H. \& Renner, S. S. 2001. Phylogeny and historical biogeography of Lauraceae: evidence from the chloroplast and nuclear genomes. Annals of the Missouri Botanical Garden 88(1): 104-134.

Madriñán, S. 2004. Lauraceae. In: Smith, N.; Mori, S. A.; Stevenson, D. W. \& Heald, S. V. Flowering plants of the Neotropics. Princeton University Press, Princeton, 204-206.

Myers, N.; Mittermeier, R. A.; Mittermeier, C. G.; Fonseca, G. A. B. \& Kent, J. 2000. Biodiversity hotspots for conservation priorities. Nature 403: 853-858. 
Oliveira-Filho, A. T. \& Fontes, M. A. L. 2000. Patterns of floristic differentiation among Atlantic forests in southeastern of Brazil and the influence of climate. Biotropica 32(4b): 793-810.

Quinet, A. 2005. Sinopse taxonômica da família Lauraceae no estado do Rio de Janeiro. Acta Botanica Brasilica 19(3): 563-572.

Rohwer, J. G. 1986. Prodromus einer monographie der gattung Ocotea Aubl. (Lauraceae), sensu lato. Mitteilungen aus dem Institut für Allgemeine Botanik Hamburg 20(1): 1-278.

Rohwer, J. G. 1993. Lauraceae. In: Kubitzki K.; Rohwer, J. G. \& Bittrich, V. The families and genera of vascular plants. SpringerVerlag, Berlin, 2: 366-391.
Stuessy, T.F. 1990. Plant taxonomy, the systematic evaluation of comparative data. Columbia University Press, New York. 514p.

Thiers, B. [continuously updated]. Index Herbariorum: A global directory of public herbaria and associated staff. New York Botanical Garden's Virtual Herbarium. http://sweetgum.nybg.org/ih/.

van der Werff, H. 1991. A key to the genera of Lauraceae in the New World. Annals of the Missouri Botanical Garden 78(2): 377-387.

van der Werff, H. 2002. A synopsis of Ocotea (Lauraceae) in Central America and southern Mexico. Annals of the Missouri Botanical Garden 89(3): 429-451. 